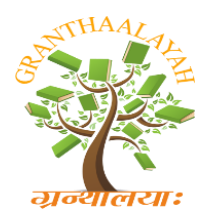

INTERNATIONAL JOURNAL OF RESEARCH GRANTHAALAYAH

A knowledge Repository

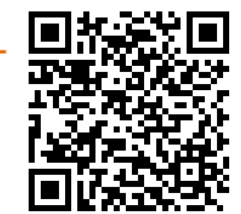

Social

\title{
PROFESSIONAL COMMUNICATION AND ITS ROLE IN LIBRARY DEVELOPMENT: A STUDY
}

\author{
Dr. S.M. Rokade * \\ ${ }^{* 1}$ University Librarian, Gondwana University, Gadchiroli, INDIA
}

\begin{abstract}
The paper succinctly describes the term Professional communication, different types of managers of libraries, type of institutions and their users, sources used by the librarian for professional communication and its role in library development. The survey was carried out through personal communication and discussion and was observed that computer, Internet, Intranet, Ethernet, email, mobile and TV are the $100 \%$ main means of library professional communication and $93.33 \%$ SMS , $91.11 \%$ work, $85.55 \%$ seminar, $75.55 \%$ Twitter, $61.11 \%$ articles, $56.66 \%$ verbal, $54 \%$ meeting, $48.33 \%$ membership of associations, $47 \%$ written, 30.55 share it, $30 \%$ meeting, $26 \%$ fax, $25 \%$ chat and program, $12.22 \%$ VoIP, 18.88 survey, 17.77 speeches, $11.11 \%$ radio, 8.33 blog, 6.66 messages were used by the library professionals for transfer and distribute of information and exchange of knowledge, ideas, and experiences amongst themselves. The four types of attitudes observed in professional communication i.e. Passive, Passive Aggressive, Aggressive, and Assertive. The professional communication maintains interrelation and avoids misunderstandings and is quite useful for the development of library.
\end{abstract}

Keywords:

Library Professional, communication, users, sources.

Cite This Article: Dr. S.M. Rokade, "PROFESSIONAL COMMUNICATION AND ITS ROLE IN LIBRARY DEVELOPMENT: A STUDY" International Journal of Research Granthaalayah, Vol. 4, No. 3 (2016): 188-191.

\section{INTRODUCTION}

The main aim and object of library is to provide information services to the users skillfully and for this there is need to develop professional communication in changing scenario among the librarians and their subordinates. Normally communicating with others is a part of everyday life and in large part, communication is about explicit language speaking and writing words but communication is also about implicit messages, such as tone, or eye contact. Communicate effectively both implicitly and explicitly is a valuable skill for any professional and librarians are not exception to this. There are various types of communication methods like written, oral, and graphic, internet and computers are widely used by the people. 


\section{OBJECTIVES OF THE STUDY}

- To know the term professional communication

- To identify the different types of managers of libraries and their users

- To find out the role of library professional communication in Library Development

- To observe components of and considerations for proper and smooth communication

- To draw the impact of professional communication in various ways

\section{PROFESSIONAL COMMUNICATION}

The ability to communicate is an essential life skill and one that can be continually developed. Individuals who are good communicators find it easy to develop empathy and trust with others. These people adapt their style of communication to suit the audience and situation they are presented with. The term professional communication refers to the various forms of speaking, listening, writing, and responding carried out both in and beyond the workplace, whether in person or electronically.

\subsection{DEFINITIONS}

Cheng and Kong (2009) point out in the preface to Professional Communication: Collaboration between Academics and Practitioners, "Professional communication is an emerging area of investigation in many disciplines such as applied linguistics, communication studies, education, and psychology.

Alice Duer Miller; "Listening is not merely not talking, "said poet Alice Duer Miller. "You can listen like a blank wall or like a splendid auditorium where every sound comes back fuller and richer."

\section{LIBRARY HEAD AND MAIN USERS OF LIBRARIES}

The libraries are the power house of generation of knowledge having designated heads to manage the same and users are real beneficiaries and considering this data has been collected and analyzed to know the status.

Table 4.1: Types of Libraries, their designated heads and users

\begin{tabular}{|l|l|l|}
\hline Type of Institution & Designation of Head & Users \\
\hline $\begin{array}{l}\text { Educational Institutions } \\
\begin{array}{l}\text { University Library } \\
\text { Sollege Library }\end{array}\end{array}$ & $\begin{array}{l}\text { University Librarian } \\
\text { College Librarian } \\
\text { Librarian }\end{array}$ & $\begin{array}{l}\text { Students, Academic staff, Research } \\
\text { scholars, Teachers, Other staff }\end{array}$ \\
\hline $\begin{array}{l}\text { Research Institution } \\
\text { Research Institution } \\
\text { Research Centers } \\
\begin{array}{l}\text { Research Organizations } \\
\text { Knowledge Resource Center }\end{array}\end{array}$ & $\begin{array}{l}\text { Librarian/Information } \\
\text { Scientist/Director }\end{array}$ & $\begin{array}{l}\text { Research scholars, Scientists, } \\
\text { Subject Matter specialists }\end{array}$ \\
\hline Public Libraries & & \\
\hline
\end{tabular}




\begin{tabular}{|l|l|l|}
\hline $\begin{array}{l}\text { District Public Libraries } \\
\text { State level /Public Information } \\
\text { Centers }\end{array}$ & Librarian/ Director & $\begin{array}{l}\text { All types of common users from the } \\
\text { public of any status }\end{array}$ \\
\hline $\begin{array}{l}\text { Other Libraries Department } \\
\text { Other } \\
\begin{array}{l}\text { Libraries/NGO/Special } \\
\text { Libraries }\end{array}\end{array}$ & Librarian & Particular type of users \\
\hline
\end{tabular}

Source: Communication and personal discussion

\section{SOURCES USED FOR LIBRARY PROFESSIONAL COMMUNICATION}

The survey was carried out of various types' of 180 institutional librarians to find out the types and sources used by librarians for professional communication.

Table 5.1: Library Professional Communication and Sources

\begin{tabular}{|l|l|l|l|l|l|l|l|l|l|}
\hline $\begin{array}{l}\text { Unit } \\
\text { Tota } \\
1 \\
180\end{array}$ & $\begin{array}{l}\text { Internet } \\
\text { Ethernet } \\
\text { Ethem }\end{array}$ & email & $\begin{array}{l}\text { Whats } \\
\text { App }\end{array}$ & $\begin{array}{l}\text { Face } \\
\text { book }\end{array}$ & Twitter & $\begin{array}{l}\text { Video } \\
\text { calling }\end{array}$ & Shareit & Blog & $\begin{array}{l}\text { Mobil } \\
\mathrm{e}\end{array}$ \\
\hline Unit & 180 & 180 & 70 & 110 & 136 & 020 & 55 & 15 & 180 \\
\hline$\%$ & 100 & 100 & 38.88 & 61,11 & 75.55 & 11.11 & 30.55 & 8.33 & 100 \\
\hline Item & Wakataki & Fax & Verbal & written & $\begin{array}{l}\text { Semina } \\
\text { r }\end{array}$ & $\begin{array}{l}\text { Memb } \\
\text { ership }\end{array}$ & TV & Radio & $\begin{array}{l}\text { Mess } \\
\text { age }\end{array}$ \\
\hline Unit & 00 & 26 & 102 & 47 & 154 & 87 & 180 & 20 & 12 \\
\hline$\%$ & 00 & 14.44 & 56.66 & 26.11 & 85.55 & 48.33 & 100 & 11.11 & 6.66 \\
\hline Item & SMS & Chat & $\begin{array}{l}\text { Speeche } \\
\text { s }\end{array}$ & VoIP & $\begin{array}{l}\text { Meetin } \\
\text { g }\end{array}$ & $\begin{array}{l}\text { Article } \\
\text { s }\end{array}$ & survey & Program & work \\
\hline Unit & 168 & 45 & 32 & 22 & 54 & 110 & 34 & 45 & 164 \\
\hline$\%$ & 93.33 & 25 & 17.77 & 12.22 & 30 & 61.11 & 18.88 & 25 & 91.11 \\
\hline
\end{tabular}

Source: Communication and personal discussion

\subsection{OBSERVATION}

It was observed from the table 2 that Internet, Intranet, Ethernet, email, mobile and TV are the $100 \%$ main means of librarians for library profession communication. The $93.33 \%$ SMS , $91.11 \%$ work, $85.55 \%$ seminar, $75.55 \%$ Twitter, $61.11 \%$ articles, $56.66 \%$ verbal, $54 \%$ meeting, $48.33 \%$ membership of associations, $47 \%$ written, 30.55 share it, $30 \%$ meeting, $26 \%$ fax, $25 \%$ chat and program, $12.22 \%$ Voice over Internet Protocol (VoIP), 18.88 survey, 17.77 speeches, $11.11 \%$ radio, 8.33 blog, 6.66 messages.

\section{ATTITUDES TO COMMUNICATIONS}

Effective communication depends on ability to read the attitude of the other person or group. There are four types of attitude: Passive, Passive Aggressive, Aggressive, and Assertive.

- 'Passive' describes someone who tends to remain silent and go along with other people's views and opinions, even if they disagree with them. 
- 'Passive Aggressive' describes someone who uses a mixture of body language, paraverbal signals, and sarcasm to undermine honest communication.

- 'Aggressive' describes someone who is not listening to or acknowledging anyone else in the exchange.

- 'Assertive' describes someone who is honest and open in their communications and allows others to express their views. Your own emotions and your awareness of others' emotions should inform your communications rather than hijack or sabotage them.

\section{ROLE OF LIBRARY PROFESSIONAL COMMUNICATION IN DEVELOPMENT}

- Present ideas clearly and logically

- Maintain interrelation and mutual understanding

- Prepare ideas in advanced for further discussion

- Effectively listen to others ideas and question them for further thinking

- Show enthusiasm about what you are talking about

- Help to avoid misunderstandings, confusion, and misinterpretations

- Allow for each member of the team to voice their opinion

- Collaboration with everybody in the team

\section{CONCLUSION}

It was concluded that in changing scenario professional communication is essential for the development of self and institute. Internet, Intranet, Ethernet, email, mobile and TV are the 100 $\%$ main means for library professional communication. The professional communication maintains interrelation and avoids misunderstandings and is helpful for the development of library.

\section{REFERENCES}

[1] Alice Duer Miller (2011)The Happiest Time of Their Lives http://www.goodreads.com/quotes/267015-people-love-to-talk-but-hate-to-listenlistening-is.

[2] http://www.esf.edu/fnrm/documents/FNRM_Communications_Handbook2008.pdf 